\title{
Homeostatic Regulation of Sleep in a Genetic Model of Depression in the Mouse: Effects of Muscarinic and 5-HT IA Receptor Activation
}

\author{
Daniela Popa*,', Malika El Yacoubi', Jean-Marie Vaugeois ${ }^{2}$, Michel Hamon' and Joëlle Adrien' \\ 'UMR 677 INSERM/UPMC, Institut National de la Santé et de la Recherche Médicale, Université Pierre et Marie Curie, \\ NeuroPsychoPharmacologie, Boulevard de l'Hôpital, Paris Cedex, France; ${ }^{2}$ Centre National de la Recherche Scientifique, UMR 6036, \\ Neuropsychopharmacologie Expérimentale, Institut Fédératif de Recherches Multidisciplinaires sur les Peptides 23, Unité de Formation et de \\ Recherche Médecine et Pharmacie, Boulevard Gambetta, Rouen Cedex, France
}

\begin{abstract}
In depressed patients, sleep undergoes marked alterations, especially sleep onset insomnia, sleep fragmentation, and disturbances of the Rapid Eye Movement (REM) sleep. Abnormalities of rest-activity rhythms and of hypothalamic-pituitary-adrenocortical function have also been described in these patients. In the present study, we examined the presence of such abnormalities in a recently developed line of mice (Helpless mice-H) that exhibit depression-like behaviors in validated tests, compared to the nonhelpless $(\mathrm{NH})$ line derived from the same colony. Experiments were essentially carried out in females for which previous studies showed marked differences between $\mathrm{H}$ and $\mathrm{NH}$ lines. Compared to $\mathrm{NH}$ mice, the $\mathrm{H}$ line exhibited (i) lower basal locomotor activity, (ii) sleep fragmentation, shift towards lighter sleep stages, and facilitation of REM sleep reflected by increased amounts and decreased latency, (iii) larger response to the REM sleep promoting effect of muscarinic receptor stimulation (by arecoline). In contrast, $\mathrm{H}$ and $\mathrm{NH}$ mice were equally responsive to the REM sleep inhibitory effect of 5-HT IA receptor stimulation (by 8-OH-DPAT). In addition, a deficiency in delta power enhancement after sleep deprivation was observed in the $\mathrm{H}$ group, and acute immobilization stress in this group failed to elicit a REM sleep rebound and was associated with a long-lasting raise in serum corticosterone levels. These results further validate $\mathrm{H}$ mice as a depression model and suggest they might be of particular interest for investigating the neurobiological mechanisms and possibly genetic substrates underlying sleep alterations associated with depression.

Neuropsychopharmacology (2006) 3 I, 1637-1646. doi:I 0.1038/sj.npp. I 300948; published online 9 November 2005
\end{abstract}

Keywords: sleep; depression; stress; REM sleep regulation; muscarinic receptors; 5-HT IA receptors; mice

\section{INTRODUCTION}

Depression is one of the most common psychiatric disorders in developed countries. It is associated with characteristic sleep impairments, notably difficulties in falling asleep, reduction of the rapid eye movement (REM) sleep latency, sleep fragmentation, and early morning awakenings (Adrien, 2002; Benca, 2000). In addition, abnormalities of circadian rhythms, affecting notably nycthemeral variations in rest-activity, and body temperature, have been described in depressed patients

\footnotetext{
*Correspondence: Dr D Popa, UMR 677 INSERM/UPMC, Faculté de Médecine Pitié Salpêtrière, 91, Boulevard de l'Hôpital, 75634 Paris Cedex 13, France, Tel: + 33 | 407797 13, Fax: + 33 | 40779790 , E-mail: popa@ext.jussieu.fr

Received 19 April 2005; revised 13 September 2005; accepted 19 September 2005

Online publication: 23 September 2005 at http://www.acnp.org/ citations/Npp092305050256/default.pdf
}

(Avery et al, 1999; Bunney and Bunney, 2000; Souetre et al, 1989).

In order to study the physiopathology of depression, several groups have attempted to develop animal models that exhibit depression-like behaviors and do respond to antidepressant therapy (Nestler et al, 2002; Overstreet, 1993; Willner, 1990). Studies of sleep patterns in these various models might help to elucidate the mechanisms underlying the relationship between depression and sleep abnormalities. To date, these aspects have only been studied in a few of these models, and mostly in rats (Adrien et al, 1991; Dugovic et al, 2000; Overstreet, 1993; Willner, 1990). We recently developed a line of mice selected from its long duration immobility in the tail suspension test ('Helpless' $\mathrm{H})$, compared to 'non-Helpless' (NH) mice which exhibited short duration immobility in the test (El Yacoubi et al, 2003). H mice exhibited several neurochemical and behavioral impairments, that mimic those found in depression, with notably an increased pressure of REM sleep and a lighter slow wave sleep (SWS) (El Yacoubi et al, 2003). Here, 
to further assess the relevance of $\mathrm{H}$ mice as a model of depression, we detail these sleep impairments and we examine the cycle of locomotor activity and body temperature over the dark-light cycle. Moreover, we monitored sleep responses to pharmacological and behavioral challenges.

Depression is schematically associated with a general increase in cholinergic and decrease in serotonergic neurotransmission (Gillin et al, 1991; Hasler et al, 2004; Kapitany et al, 1999; Seifritz et al, 1998). To test for the presence of such imbalance between cholinergic and serotonergic function in $\mathrm{H}$ mice, we investigated the sleep modifications induced by treatments with agonists of muscarinic and serotonergic $5-\mathrm{HT}_{1 \mathrm{~A}}$ receptors in both $\mathrm{H}$ and $\mathrm{NH}$ mice.

It has been well documented that sleep regulation depends on a homeostatic drive (Borbely et al, 1981). During recovery from sleep deprivation, this homeostatic drive notably causes an increase of slow wave activity (SWA) assessed by quantitative EEG measures, in humans (Borbely et al, 1981), rats (Borbely et al, 1981; Tobler and Borbely, 1990), as well as mice (Franken et al, 2001; Lena et al, 2004; Tobler et al, 1997). The magnitude of SWA depends on the duration of prior waking (Tobler and Borbely, 1990), which suggests that SWA is a marker for sleep intensity (Borbely et al, 1981). On the other hand, it has been shown that stress-elicited activation of the hypothalamo-pituitary-adrenocortical (HPA) axis triggers a REM sleep rebound (Boutrel et al, 2002; Lena et al, 2004; Rampin et al, 1991). In depressed patients, both sleep homeostasis (Armitage et al, 2000; Borbely, 1987) and HPA axis activity (Barden et al, 1995) are frequently altered. Accordingly, the effects of sleep deprivation and of immobilization stress on subsequent sleep parameters were also investigated in $\mathrm{H} v s \mathrm{NH}$ mice.

\section{MATERIALS AND METHODS}

All the procedures involving animals and their care were conducted in conformity with the institutional guidelines that are in compliance with national and international laws and policies (Council directive \# 87-848, October 19, 1987, Ministère de l'agriculture et de la forêt, Service vétérinaire de la santé et de la protection animale, permissions \# 75-116 to M.H. and \# 75-125 to JA).

All mice used for these studies were of the $\mathrm{H}$ and $\mathrm{NH}$ lines (CD1 strain), selected across 12-14 generations for high or low spontaneous 'helplessness' in the tail suspension test, as described previously (El Yacoubi et al, 2003). For the study of spontaneous sleep-wakefulness patterns, both males and females were used. For all other experiments, data were collected from females only. Indeed, previous studies showed that differences between $\mathrm{H}$ and $\mathrm{NH}$ mice (regarding notably adaptive behavioural and neurobiological responses to chronic treatment with antidepressants) were larger in females than in males (El Yacoubi et al, 2003).

\section{Recordings of Locomotor Activity and Body Temperature}

At 2-3 months of age, female mice of both $\mathrm{H}$ and $\mathrm{NH}$ lines were anaesthetized with sodium pentobarbital $(75 \mathrm{mg} / \mathrm{kg}$ intraperitoneally(i.p.)) and implanted into the abdomen with a mini-emitter (Mini-Mitter ${ }^{\circledR}$ Co, Bend, OR, USA) for monitoring locomotor activity and body temperature. After completion of surgery, animals were housed in individual cages under standard laboratory conditions (12-12 h lightdark cycle (light on at 0700), food and water ad libitum, $24 \pm 1^{\circ} \mathrm{C}$ ambient temperature), and were allowed 10-14 days to recover. Thereafter, each animal was recorded during 8 days, that is across two successive ovarian cycles. Data were collected on a computer with Vitalview software (Mini-Mitter ${ }^{\circledR} \mathrm{Co}$ ). Body temperature was measured at a constant acquisition rate of once per second, and averaged over 5 min-periods. For the measurement of locomotor activity, position and orientation of the abdominal emitter relative to the receiver were determined every second, and changes in these parameters were summed over $5 \mathrm{~min}$ periods to yield activity counts.

\section{Implantation of Electrodes for Polygraphic Sleep-Wakefulness Monitoring}

At 2-3 months of age, male and female mice of the $\mathrm{H}$ and $\mathrm{NH}$ lines were implanted under sodium pentobarbital anaesthesia $(75 \mathrm{mg} / \mathrm{kg}$ i.p. $)$ with the classical set of electrodes (made of enameled nichrome wire, $150 \mu \mathrm{m}$ in diameter) for polygraphic sleep monitoring. Briefly, EEG electrodes were inserted through the skull onto the dura over the right cerebral cortex $(2 \mathrm{~mm}$ lateral and $4 \mathrm{~mm}$ posterior to the bregma) and over the cerebellum (at midline, $2 \mathrm{~mm}$ posterior to lambda), EOG electrodes were positioned under the skin on each side of the orbit, and EMG electrodes were inserted into the neck muscles. All electrodes were anchored to the skull with super-bond and acrylic cement, and soldered to a mini-connector also embedded in cement (Boutrel et al, 1999). After completion of surgery, animals were housed in individual cages $(20 \times 20 \times 30 \mathrm{~cm})$ and maintained under standard laboratory conditions (see above). They were allowed 10-14 days to recover, during which they were habituated to the recording conditions, that is one animal per cage, the homecage being the recording cage.

\section{Recording of Sleep-Wakefulness Cycles}

After the animals had been habituated to the recording cable for 2 days, polygraphic recording of the spontaneous sleep wakefulness states was performed during $48 \mathrm{~h}$ for males and $96 \mathrm{~h}$ for females, beginning at 1900, that is at the onset of the dark period.

\section{Power Spectra Analysis}

The EEG signal was processed for power spectra analysis (Franken et al, 1998; Lena et al, 2004). For each animal under well-defined experimental conditions, a spectrogram was obtained and the values for power spectra were divided into four frequency bands: delta $(0.5-4.99 \mathrm{~Hz})$, theta $(5-$ $9.99 \mathrm{~Hz})$, spindles $(10-19.99 \mathrm{~Hz})$, and high frequencies $(20-$ $60 \mathrm{~Hz}$ ). The delta and theta bands were determined according to the spectral profiles in SWS and REM sleep, respectively. EEG spectrograms and power spectra for each of the four frequency bands, expressed as a percentage of 
the mean EEG power over all frequency bands, were compared between $\mathrm{H}$ and $\mathrm{NH}$ mice under baseline conditions, after sleep deprivation and after immobilization stress.

\section{Monitoring of Estrous Cycle}

The estrous cycle was monitored in order to examine a possible relation with sleep modifications. For this purpose, vaginal smear samples from $\mathrm{H}$ and $\mathrm{NH}$ females were taken daily between 1700 and 1800, starting 4-5 days before recording spontaneous sleep cycles. Quantitative determination of leukocytes and epithelial cells in vaginal smears allowed identification of the phase of the 4 day-estrous cycle. Proestrous was characterized by the presence of numerous round epithelial cells and a small number of leukocytes; estrous by that of large, flat cornified cells and no leukocytes; metestrous by some cornified cells and numerous leukocytes; and diestrous by a minority of epithelial cells and a majority of leukocytes (Schwierin et al, 1998).

\section{Pharmacological Treatments}

Drugs were dissolved in $0.1 \mathrm{ml}$ of saline, and all injections were performed at 1000, after which polygraphic recordings were obtained until 1800. The muscarinic agonist arecoline (0.025, 0.05, 0.1 mg/kg; Sigma, St Quentin Fallavier, France) was injected i.p. whereas the 5- $\mathrm{HT}_{1 \mathrm{~A}}$ agonist 8-hydroxy-2(di-n-propylamino)tetralin (8-OH-DPAT) $(0.2,0.4$ and $0.8 \mathrm{mg} / \mathrm{kg}$; Research Biochemicals Int., Natick, MA) was injected subcutaneously (s.c.). For baseline data, mice were injected with saline, i.p. or s.c., as appropriate. A washout period of at least 2 days for arecoline and 7 days for $8-\mathrm{OH}-$ DPAT was allowed between two consecutive treatments. The effects of each dose of arecoline and 8-OH-DPAT upon each state of vigilance were analyzed for every hour following injection. For a given treatment, each animal was referred to its own baseline represented by the data obtained after injection of saline.

\section{Sleep Deprivation}

Mice were subjected to a $6 \mathrm{~h}$ sleep deprivation starting at light onset (0700). For this purpose, animals were continuously observed and objects (pencil, pieces of paper, plastic tubes) were introduced into the cage to disturb the mouse as soon as it engaged in a sleeping posture (Lena et al, 2004; Tobler et al, 1997). At the end of the deprivation period, animals were left to sleep freely and were recorded for $18 \mathrm{~h}$ (from 1300 to 0700 the next morning).

\section{Immobilization Stress}

At least 15 days after completion of the sleep deprivation procedure, mice were immobilized for $90 \mathrm{~min}$, from 1830 to 2000 , by wrapping them inside a plastic grid as described previously (Boutrel et al, 2002; Lena et al, 2004). At the end of this period, they were returned to their home cage for sleep-wakefulness monitoring during $24 \mathrm{~h}$. As a control, each mouse underwent a sham procedure (the animal remained free in its home cage from 1830 to 2000 and was connected a few minutes before being recorded during $24 \mathrm{~h}), 2$ days prior to the immobilization stress procedure.

\section{Serum Corticosterone Assay}

Serum corticosterone levels were measured immediately and $6 \mathrm{~h}$ after immobilization stress. For this purpose, animals were decapitated and their blood was collected, allowed to clot and centrifuged at $1700 \mathrm{~g}$ for $25 \mathrm{~min}$ at $4{ }^{\circ} \mathrm{C}$. Serum was then collected and stored at $-20^{\circ} \mathrm{C}$ until further analysis. Corticosterone was quantified by radioimmunoassay after extraction in ethanol (Grino et al, 1987). Anticorticosterone antiserum was generously given by $\mathrm{F}$ Héry (INSERM U297, Marseille, France). Corticosterone (Sigma) was used as standard and $\left[{ }^{3} \mathrm{H}\right]$ corticosterone (87 $\mathrm{Ci} / \mathrm{mmol}$, Amersham-Pharmacia Biotech., Les Ulis, France) as radiotracer (Grino et al, 1987).

\section{Data Analyses and Statistics}

The changes in locomotor activity and core temperature over time were analyzed using two-way ANOVA with repeated measures over time. The circadian oscillations of these variables were assessed using the Cosinor ${ }^{\circledR}$ software (S.E.P.T.M.R., Bordeaux, France).

Polygraphic recordings were scored visually every $15 \mathrm{~s}$ epoch as wakefulness (W), SWS or REM sleep following classical criteria (Lena et al, 2004; Tobler et al, 1997), using the Somnologica ${ }^{\circledR}$ software (Flaga, Reykjavik, Island). SWS was subdivided into light $\left(\mathrm{SWS}_{1}\right)$ and deep $\left(\mathrm{SWS}_{2}\right)$ according to the criteria defined for rats (Neckelmann and Ursin, 1993) and adapted to mice: when delta waves were present during less than $50 \%$ of the epoch, it was scored as $\mathrm{SWS}_{1}$, and when this percentage was higher than $50 \%$, as $\mathrm{SWS}_{2}$.

For analysis of the spontaneous sleep-wakefulness patterns, the amounts as well as the mean duration and number of episodes of each vigilance state for each animal were calculated for every hour throughout 48 and $96 \mathrm{~h}$, in males and females, respectively, and averaged over 2 or $12 \mathrm{~h}$-cycle. Sleep fragmentation was assessed by calculating the mean duration of $\mathrm{SWS}_{2}$ episodes as well as the number of wake bouts (Dugovic et al, 2000). The mean values were expressed as minutes \pm SEM for each line of mice, and significance was tested by performing a two-way ANOVA with repeated measures over time. In case of significance $(p<0.05)$, the $\mathrm{F}$ test was followed by the Student's $t$-test for means' comparisons. For the relation between sleep and the estrous cycle, sleep amounts were evaluated every $3 \mathrm{~h}$-bin over four consecutive $24 \mathrm{~h}$-periods.

For pharmacological experiments, the effects of each dose of arecoline and 8-OH-DPAT upon REM sleep latency (defined as the delay between sleep onset after the injection, and the first REM sleep episode) and the amounts of each state of vigilance for every hour following injection were analyzed. For a given treatment, each animal was referred to its own baseline represented by the data obtained after injection of saline. Statistical analyses were performed using two-way ANOVA for factors treatment and group, and in case of significance $(p<0.05)$, the $\mathrm{F}$ test was followed by the Dunnett's $t$ test for means' comparisons. 
For each animal, the sleep amounts and EEG power spectra values after total sleep deprivation or immobilization stress sessions were compared with their respective control values. Differences between baseline and recovery from sleep deprivation or immobilization stress were assessed by means of the paired two-tailed Student's $t$-test.

\section{RESULTS}

\section{Locomotor Activity and Body Temperature}

Both $\mathrm{H}$ and $\mathrm{NH}$ mice exhibited a diurnal rhythm of locomotor activity and body temperature characterized by higher levels during the dark than during the light period (Figure 1). However, the amplitude of the activity rhythm was significantly smaller in $\mathrm{H}$ compared with $\mathrm{NH}$ mice (in counts per $5 \mathrm{~min}$ (see Figure 1): $7.9 \pm 0.3$ and $14.1 \pm 2.2$, respectively, $n=6$ in each group, $p<0.05$ ), due to a lesser locomotor activity in helpless animals, with notably an absence of peaks at the beginning and the end of the light period (ANOVA: $\mathrm{F}_{1,1430}=11.3, p<0.01$ ), and during the first half of the dark period $\left(\mathrm{F}_{1,1430}=7.9, p<0.05\right)$ (Figure 1a). In contrast, core temperature was globally the same in both lines during the dark period, but was lower in $\mathrm{H}$ compared to $\mathrm{NH}$ mice during the light period $\left(\mathrm{F}_{1,1430}=7.2, \quad p=<0.05\right)$. In particular, no peaks of temperature at the beginning and at the end of the light period were observed in $\mathrm{H}$ mice, in contrast to those occurring in $\mathrm{NH}$ mice (Figure $1 \mathrm{~b}$ ).
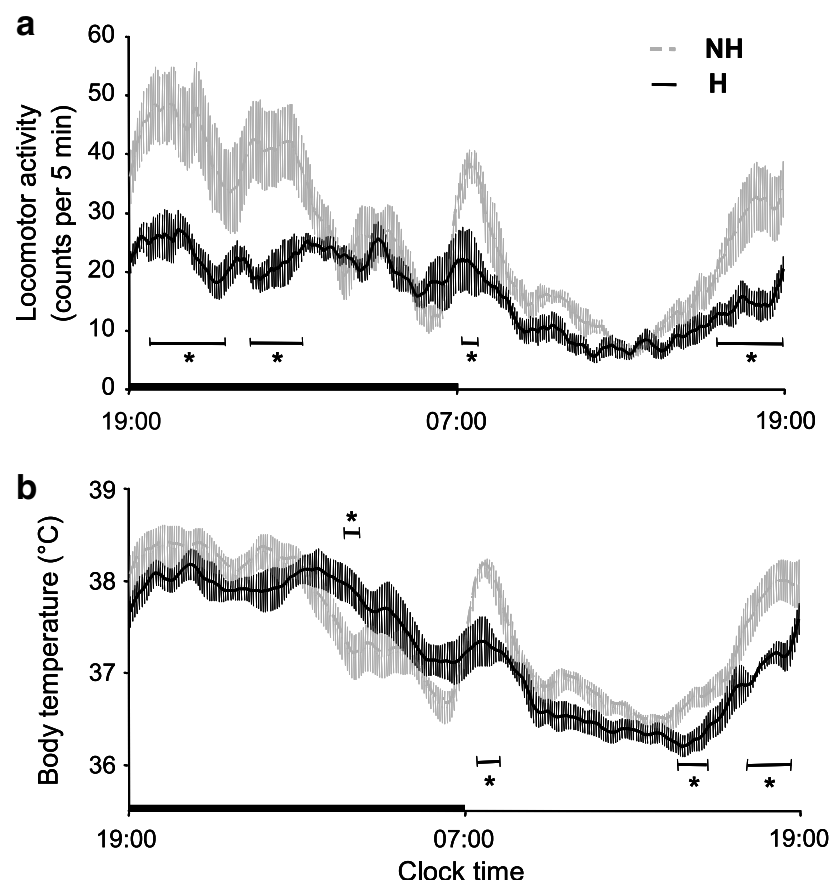

Figure I Locomotor activity (a) and body temperature (b) in $\mathrm{NH}$ (dashed line) and $\mathrm{H}$ (solid line) mice. Data (mean \pm SEM of 6 animals in each group) are expressed every 5 min as counts for activity and as ${ }^{\circ} \mathrm{C}$ for temperature. ${ }^{*} p<0.05$, significantly different between $\mathrm{H}$ and $\mathrm{NH}$ mice; unpaired Student's $t$ test.

\section{Sleep and Wakefulness}

Under baseline conditions. Both lines of mice exhibited similar EEG spectra (Table 1) and diurnal rhythm of sleep and wakefulness, with larger amounts of sleep during the light period than during the dark one (Figure 2). However, marked differences in the amounts of sleep and wakefulness were observed between the two lines. For both males and females, $\mathrm{H}$ mice exhibited significantly lower levels of wakefulness (ANOVA: $\mathrm{F}_{1,220}=23.0, p<0.001$ ) and greater amounts of REM sleep $\left(\mathrm{F}_{1,220}=21.2, p<0.001\right)$ and $\mathrm{SWS}_{1}$ $\left(\mathrm{F}_{1,220}=78.0, p<0.001\right)$ across the $24 \mathrm{~h}$, compared to $\mathrm{NH}$ mice (Figure 2, Table 2). $\mathrm{SWS}_{2}$ was increased at the beginning of the dark period (Figure 2) but represented in the whole a smaller proportion of total sleep in $\mathrm{H}$ than in NH mice (Table 2). These modifications were accompanied by a decrease in the mean duration of $\mathrm{SWS}_{2}$ episodes (in min: females, $\mathrm{H}: 1.31 \pm 0.12$ vs $\mathrm{NH}: 2.21 \pm 0.23, p<0.05$; males, $\mathrm{H}: 1.00 \pm 0.05$ vs $\mathrm{NH}: 1.58 \pm 0.25, p<0.05)$, and an increase in the number of wakefulness episodes notably in females $(\mathrm{H}: 151.17 \pm 6.15$ vs $\mathrm{NH}: 107.89 \pm 15.51 / 24 \mathrm{~h}$, $p<0.05)$, both parameters providing an index of sleep fragmentation (Dugovic et al, 2000).

In females, amounts of sleep and wakefulness varied across the estrous cycle only in $\mathrm{NH}$ mice, with less time spent in REM sleep between 2100 and 2300 at the proestrous period (in minutes: $2.6 \pm 0.5$ vs $4.9 \pm 1.1$ in estrous, $p<0.05$ ). There were no other changes in the vigilance states in $\mathrm{NH}$ mice, and EEG spectra did not significantly vary across the estrous cycle in either $\mathrm{NH}$ or $\mathrm{H}$ mice (not shown).

With respect to both spontaneous sleep-wakefulness characteristics and responses in depression-related behavioural tests (El Yacoubi et al, 2003), females of the $\mathrm{H}$ line were generally more affected than males. Accordingly, the following studies were performed only with females.

Pharmacological activation of muscarinic and $5-H T_{1 A}$ receptors. Under vehicle injection, REM sleep latency was significantly shorter in $\mathrm{H}$ than in $\mathrm{NH}$ mice (in minutes: $\mathrm{H}: 16.5 \pm 3.6$ vs NH: $30.2 \pm 4.2, n=8-9, p<0.01$ ).

Acute administration of the muscarinic agonist arecoline (0.025-0.1 mg/kg, i.p.) did not modify REM sleep amounts (during $2 \mathrm{~h}$ after injection: $\mathrm{NH}: \mathrm{F}_{3,29}=1.4, p<0.3 ; \mathrm{H}$ : $\mathrm{F}_{3,21}=1.6, \mathrm{p}=0.2$; not shown) but produced a significant decrease in REM sleep latency in both mouse lines (NH: $\mathrm{F}_{3,32}=10.2, p<0.0001 ; \mathrm{H}: \mathrm{F}_{3,23}=8.4, p<0.001$ ) (Figure 3a).

Table I Power Spectra of the EEG Frequency Bands During $\mathrm{SWS}_{2}$ and REM Sleep in Female $\mathrm{NH}$ and $\mathrm{H}$ mice

\begin{tabular}{lccccc}
\hline & \multicolumn{2}{c}{ SWS $_{2}$} & & \multicolumn{2}{c}{ REM } \\
\cline { 2 - 3 } \cline { 6 - 7 } \% Total power & NH & H & & NH & H \\
\hline Delta $(0.5-4.99 \mathrm{~Hz})$ & $34.4 \pm 2.8$ & $40.4 \pm 3.9$ & & $24.7 \pm 2.9$ & $20.1 \pm 2.2$ \\
Theta $(5-9.99 \mathrm{~Hz})$ & $28.2 \pm 0.7$ & $27.8 \pm 1.4$ & $33.1 \pm 1.4$ & $38.7 \pm 2.4$ \\
Spindles $(10-19.99 \mathrm{~Hz})$ & $23.8 \pm 1.1$ & $20.6 \pm 1.6$ & & $25.4 \pm 1.6$ & $23.1 \pm 0.9$ \\
High frequency $(20-60 \mathrm{~Hz})$ & $13.6 \pm 1.4$ & $11.1 \pm 1.6$ & & $16.9 \pm 1.4$ & $18.3 \pm 2.4$ \\
\hline
\end{tabular}

Results (mean \pm SEM of 10 and 12 animals, respectively) are expressed for every animal as percentage of the total power during $24 \mathrm{~h}$. 


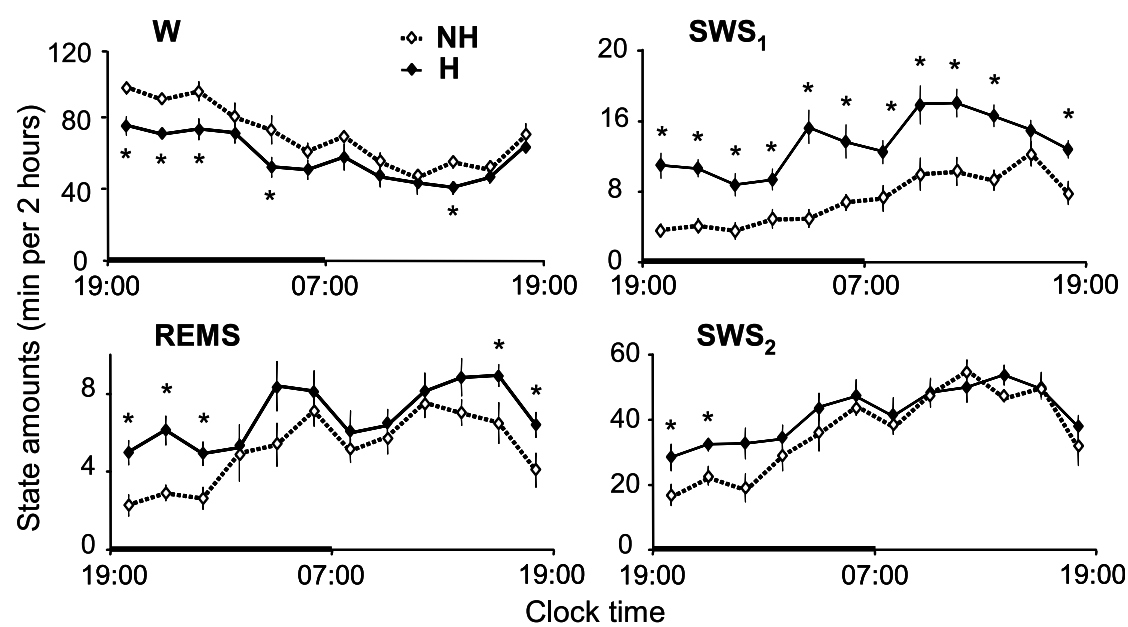

Figure 2 Variations of $W, S W S_{1}, S_{2}$ and REM sleep across the light-dark cycle in $\mathrm{NH}$ (dotted line) and $\mathrm{H}$ (solid line) mice. Data (mean \pm SEM of I0 and 12 animals, respectively) are expressed as minutes per $2 \mathrm{~h}$ during $24 \mathrm{~h} .{ }^{*} \mathrm{p}<0.05$, significantly different from $\mathrm{NH}$ mice; unpaired Student's $t$ test.

Table 2 Amounts of $\mathrm{W}, \mathrm{SWS}_{1}, \mathrm{SWS}_{2}$, and REMS in $\mathrm{NH}$ and $\mathrm{H}$ Mice Under Baseline Conditions

\begin{tabular}{|c|c|c|c|c|c|c|c|c|c|c|}
\hline & \multirow[b]{2}{*}{ Period } & & \multicolumn{2}{|c|}{$\mathbf{W}$} & \multicolumn{2}{|c|}{ SWS, } & \multicolumn{2}{|c|}{ SWS $_{2}$} & \multicolumn{2}{|c|}{ REM sleep } \\
\hline & & & q & $\hat{0}$ & q & 0 & q & $\hat{0}$ & q & $\hat{0}$ \\
\hline & & $\%$ TST & & & $13.0 \pm 0.8$ & $14.0 \pm 1.1$ & $75.8 \pm 1.1$ & $73.4 \pm 0.6$ & $11.2 \pm 0.8$ & $12.6 \pm 1.0$ \\
\hline & Light & Min & $369.5 \pm 13.9$ & $344.6 \pm 26.3$ & $47.7 \pm 4.4$ & $55.0 \pm 6.1$ & $265.5 \pm 10.6$ & $287.3 \pm 21.7$ & $37.2 \pm 3.2$ & $33.1 \pm 5.0$ \\
\hline \multirow[t]{4}{*}{$\mathrm{H}$} & Dark & Min & $419.4 \pm 16.6 *$ & $389.0 \pm 9.6$ & $62.6 \pm 5.1 *$ & $87.2 \pm 1.8 *$ & $197.7 \pm 13.1$ & $198.5 \pm 8.5$ & $40.3 \pm 1.8 *$ & $45.2 \pm 1.6$ \\
\hline & & $\%$ TST & & & $20.8 \pm 1.1 *$ & $26.4 \pm 0.7 *$ & $65.4 \pm 1.6 *$ & $59.9 \pm 0.9 *$ & $13.8 \pm 1.1$ & $13.7 \pm 0.5$ \\
\hline & Light & Min & $307.3 \pm 16.2 *$ & $257.0 \pm 2.4 *$ & $96.7 \pm 3.7 *$ & $119.4 \pm 6.5^{*}$ & $266.9 \pm 13.3$ & $297.9 \pm 7.4$ & $49.2 \pm 3.3^{*}$ & $48.7 \pm 3.4 *$ \\
\hline & & $\%$ TST & & & $23.8 \pm 1.2 *$ & $25.6 \pm 1.3 *$ & $64.4 \pm 1.2 *$ & $64.0 \pm 1.8 *$ & $11.8 \pm 0.6$ & $10.4 \pm 0.7$ \\
\hline
\end{tabular}

Results are expressed as minutes (mean \pm SEM of four to 12 animals in each group) and as percent of total sleep time (TST) during the $12 \mathrm{~h}$ of the light (0700-1900) and of the dark (1900-0700) periods.

* $p<0.05$, significantly different from NH mice; unpaired Student's $t$ test.

The latter phenomenon was larger in $\mathrm{H}$ than in $\mathrm{NH}$ mice at all doses tested. No effects of arecoline on the other states of vigilance were observed in either line of mice.

In both lines, $8-\mathrm{OH}-\mathrm{DPAT}(0.2-0.8 \mathrm{mg} / \mathrm{kg}$, s.c.) induced, during the first $2 \mathrm{~h}$-period after injection, similar dosedependent reduction of REM sleep amounts ( $\mathrm{NH}$ mice: $\mathrm{F}_{3,25}=31.6, p<0.0001 ; \mathrm{H}$ mice: $\left.\mathrm{F}_{3,19}=39.6, p<0.0001\right)$, (Table 3) and increase in REM sleep latency ( $\mathrm{NH}$ mice: $\mathrm{F}_{3,23}=9.2, \quad p<0.001 ; \quad \mathrm{H}$ mice: $\mathrm{F}_{3,15}=11.4, \quad p<0.001$ ) (Figure 3b). During the same time, the amounts of wakefulness were increased, while those of $\mathrm{SWS}_{2}$ were concomitantly decreased, but these 8-OH-DPAT-induced changes were of similar magnitude in both $\mathrm{H}$ and $\mathrm{NH}$ mice (Table 3).

After sleep deprivation (for $6 h$, starting at the onset of the light phase). $\mathrm{H}$ but not $\mathrm{NH}$ mice exhibited a significant increase in $\mathrm{SWS}_{2}$ amounts during the first $12 \mathrm{~h}$ of the recovery period (Figure $4 \mathrm{a}$ ). In contrast, EEG power density in the delta frequency range $(0.5-4.99 \mathrm{~Hz})$ was significantly increased above baseline values during the first $6 \mathrm{~h}$ of recovery in $\mathrm{NH}$ but not $\mathrm{H}$ mice (Figure $4 \mathrm{~b}$ and c). No differences between the two lines were observed in the other frequency bands examined for EEG power density analysis (not shown). In addition, no significant modifications of the other states of vigilance were observed in $\mathrm{NH}$ and $\mathrm{H}$ mice after sleep deprivation.

After immobilization stress. NH mice exhibited a significant increase in the amounts of REM sleep from the 4th to the 9 th $\mathrm{h}$ of the recovery period (Figure $5 \mathrm{a}$ ), whereas $\mathrm{H}$ mice did not (Figure $5 b$ ). In both groups, EEG power spectra activities during SWS or REM sleep were not modified. Serum corticosterone levels increased markedly immediately after the stress session in both lines $(\mu \mathrm{g} / \mathrm{ml}$ : NH: control: $21.8 \pm 7.4$, stress: $66.1 \pm 4.3, p<0.01$; $\mathrm{H}$ : control: $17.8 \pm 4.4$, stress: $74.8 \pm 7.2, p<0.01$ ). After $6 \mathrm{~h}$, these levels were still significantly elevated in the $\mathrm{H}$ mice (control: $4.9 \pm 1.1$, stress: $15.8 \pm 1.7, p<0.01)$ but had returned to basal values in $\mathrm{NH}$ mice (control: $4.5 \pm 2.0$, stress: $7.2 \pm 2.0$ not significantly different from control values in non stressed mice) (Figure 5). 

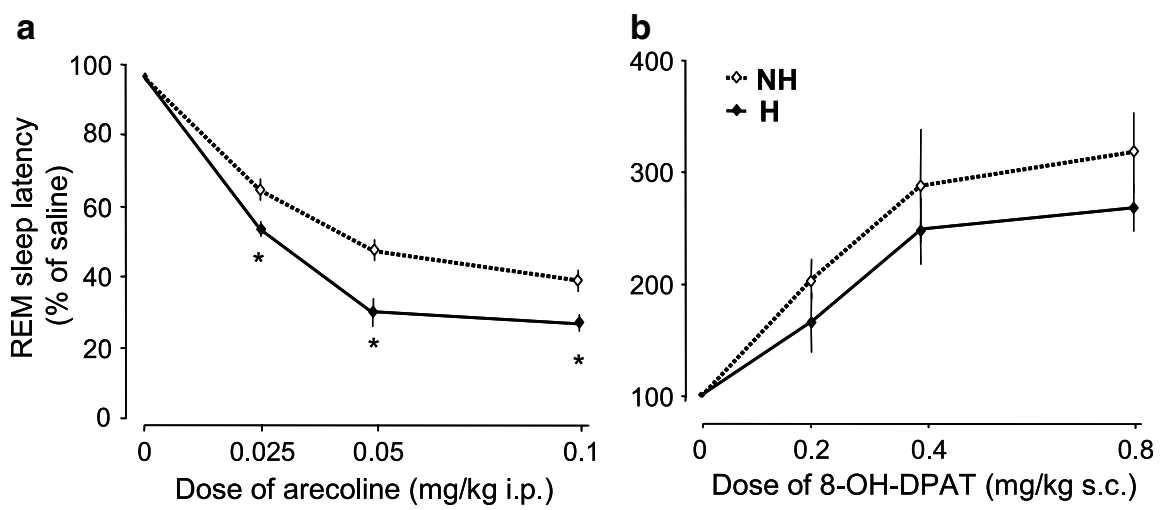

Figure 3 Effects of the muscarinic receptor agonist arecoline (a) and of the 5-HTIA receptor agonist 8-OH-DPAT (b) at various doses on REM sleep latency in $\mathrm{NH}$ (dotted line) and $\mathrm{H}$ (solid line) mice. Data (mean \pm SEM of 9 and 8 animals, respectively, for arecoline, and of 7 and 5 animals, respectively, for 8-OH-DPAT) are expressed as percent of REM sleep latency in saline-treated mice ( 0 on abscissa). $* 0<0.05$, significantly different from $\mathrm{NH}$ mice; post hoc Dunnett's test.

Table 3 Effects of the 5-HT IA Receptor Agonist 8-OH-DPAT at Various Doses on W, SWS 2 and REM Sleep in $\mathrm{NH}$ and $\mathrm{H}$ Mice

\begin{tabular}{|c|c|c|c|c|}
\hline & & \multicolumn{3}{|c|}{ 8-OH-DPAT mg/kg } \\
\hline & & 0.2 & 0.4 & 0.8 \\
\hline \multirow[t]{2}{*}{ W } & $\mathrm{NH}$ & $109.5 \pm 29.5$ & $125.8 \pm 16.7$ & $151.6 \pm 21.9 *$ \\
\hline & $\mathrm{H}$ & $138.4 \pm 18.0$ & $154.5 \pm 7.0 *$ & $162.6 \pm 10.3 *$ \\
\hline \multirow[t]{2}{*}{$\mathrm{SWS}_{2}$} & $\mathrm{NH}$ & $88.9 \pm 20.7$ & $88.9 \pm 16.6$ & $72.3 \pm 17.6 *$ \\
\hline & $\mathrm{H}$ & $84.1 \pm 11.4$ & $69.1 \pm 8.5^{*}$ & $55.4+\mid 9.1 *$ \\
\hline \multirow[t]{2}{*}{ REM sleep } & $\mathrm{NH}$ & $68.8 \pm 8.1 *$ & $28.3 \pm 6.0 *$ & $20.6 \pm 9.4 *$ \\
\hline & $\mathrm{H}$ & $54.9 \pm 8.2 *$ & $28.4 \pm 9.6 *$ & $13.7 \pm 4.3^{*}$ \\
\hline
\end{tabular}

Data (mean \pm SEM of 7 and 5 animals, respectively) are expressed as percent of saline treatment.

${ }^{*} p<0.05$, significantly different from saline; paired Student's $t$ test.

\section{DISCUSSION}

The main objective of this study was to investigate the locomotor activity, body temperature and sleep-wakefulness regulation in a novel model of depression derived from selective breeding in mice (El Yacoubi et al, 2003). Several differences were found between $\mathrm{H}$ and $\mathrm{NH}$ mice in this study. Indeed, the $\mathrm{H}$ line exhibited flattened activity rhythms, an enhanced cholinergic sensitivity of REM sleep, and abnomal responses to sleep deprivation and acute stress. Therefore, a large number of the deficiencies observed in depressed patients were also found in the $\mathrm{H}$ line.

\section{Locomotor Activity and Sleep-Wakefulness Cycles Under Baseline Conditions}

The two mouse lines exhibited circadian rhythms for sleep and wakefulness under light-dark conditions. However, $\mathrm{H}$ mice expressed a lower level of locomotor activity than $\mathrm{NH}$ mice during both the light and the dark phases that grossly
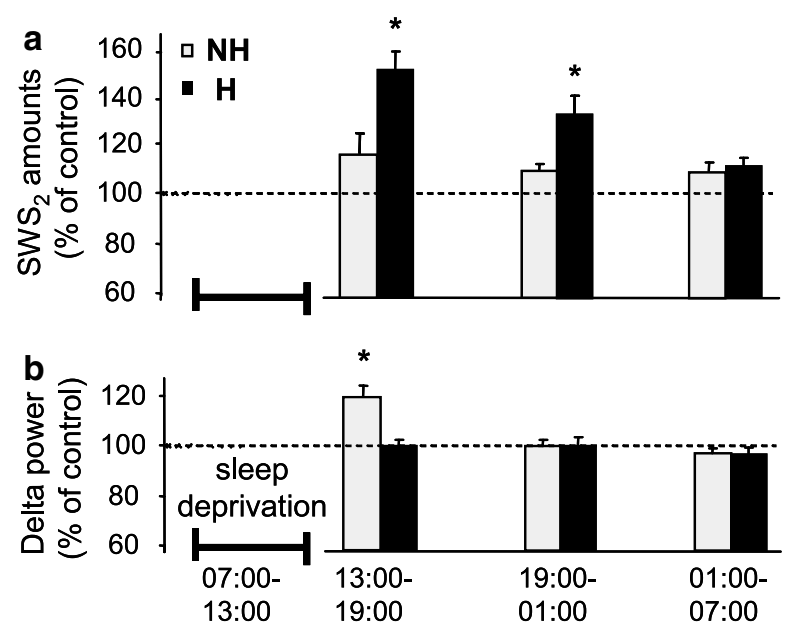

Time intervals

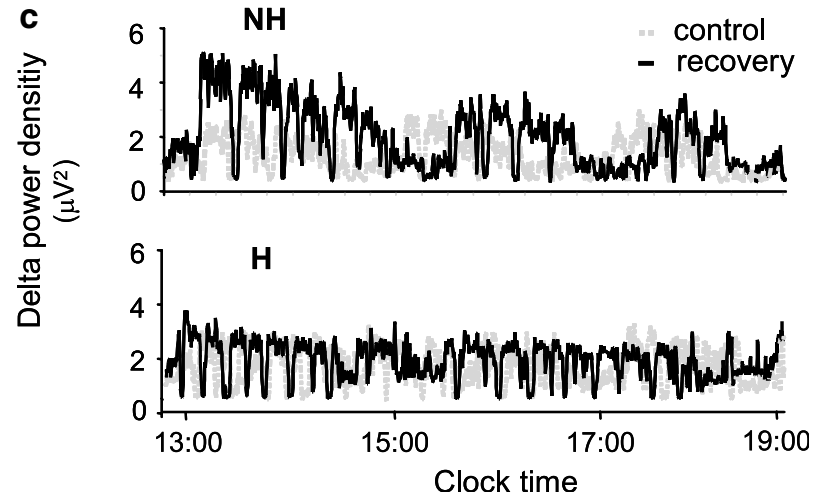

Figure 4 Effects of a 6 h-sleep deprivation starting at light onset on (a) $\mathrm{SWS}_{2}$ amounts and (b) delta power, during three consecutive $6 \mathrm{~h}$ intervals of the recovery period after sleep deprivation. Data (mean \pm SEM of $8 \mathrm{NH}$ mice (grey bars) and $8 \mathrm{H}$ mice (black bars)) are expressed as percent of the paired values obtained under control conditions. $* p<0.05$, significantly different from respective control value; paired Student's $t$ test. (c) Example of EEG delta power in $\mathrm{NH}$ (top) and $\mathrm{H}$ (bottom) mice during control (dotted line) and recovery (solid line) periods.

paralleled their reduced amounts of wakefulness. In addition, the amplitude of locomotor activity rhythm was smaller in $\mathrm{H}$ mice. These results are similar to those 

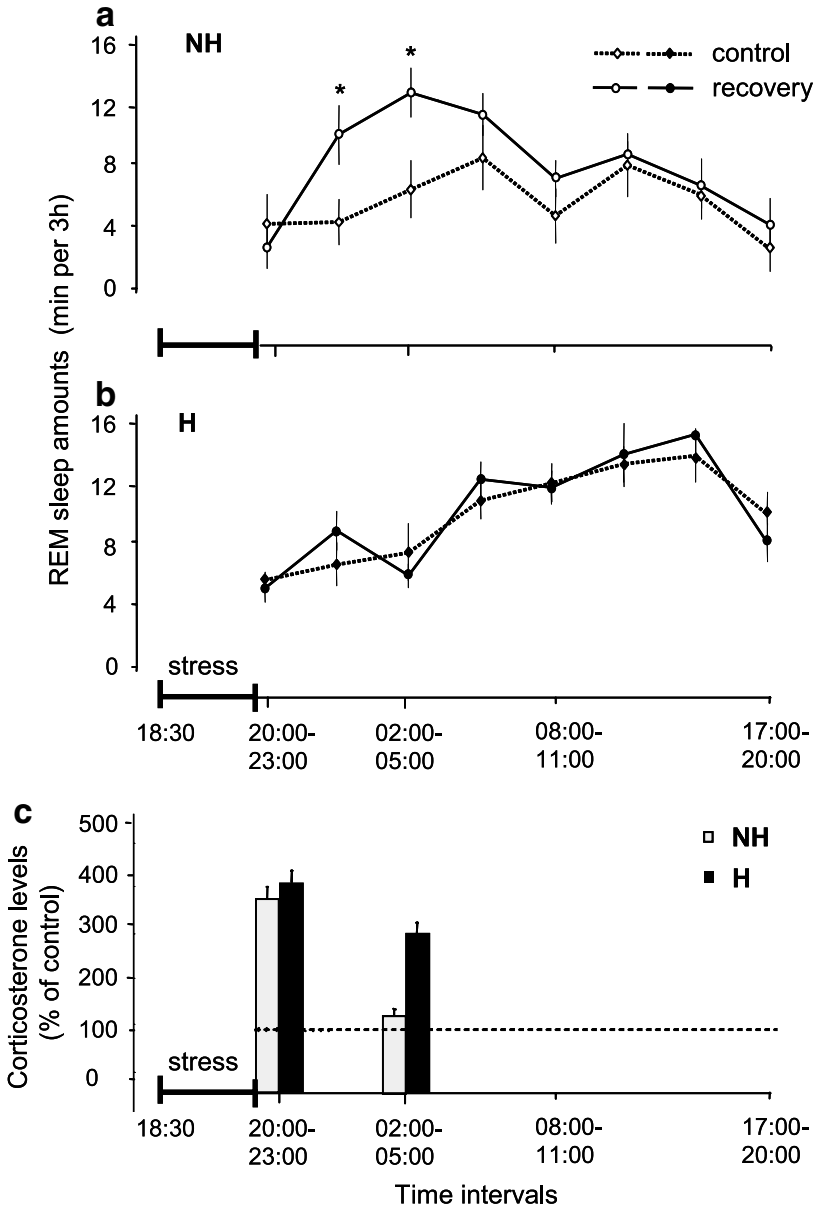

Figure 5 (a, b) REM sleep amounts during $23 \mathrm{~h}$ after $90 \mathrm{~min}$ of immobilization stress in $\mathrm{NH}$ (top) and $\mathrm{H}$ (bottom) mice. Data (mean \pm SEM of 6 animals in each group) are expressed as minutes per $3 \mathrm{~h}$ after sham conditions (dotted line) and after immobilization stress (solid line). * $p<0.05$, significantly different from respective sham control value, paired Student's $t$ test. (c) Corticosterone levels (bars; at two times: 2000 and 0200) are expressed as percent of controls at the same time (mean \pm SEM of 6 animals in each group). $* p<0.05$, significantly different from respective control values, unpaired Student's $t$ test.

reported for other animal models of depression (Overstreet, 1993; Solberg et al, 2001) and are reminiscent of the behavioural inhibition and the global flattening of circadian rhythms observed in depressed patients (Bunney and Bunney, 2000; Souetre et al, 1989).

In $\mathrm{NH}$ mice, the changes in core temperature across the $24 \mathrm{~h}$ period were directly correlated with those of locomotor activity (Bunney and Bunney, 2000). In contrast, in $\mathrm{H}$ mice, the core temperature was lower than in $\mathrm{NH}$ mice during the light period, but it rose to $\mathrm{NH}$ levels during the dark period. Interestingly, depressed patients also exhibit disruptions of the body temperature rhythm (Avery et al, 1999; Bunney and Bunney, 2000).

Both $\mathrm{H}$ and $\mathrm{NH}$ mice exhibited similar circadian variations of sleep and wakefulness, with a predominance of wakefulness during the dark period, and of sleep during the light period. These rhythms are classically observed in mice of various genetic backgrounds (Boutrel et al, 1999; Boutrel et al, 2002; Franken et al, 1998; Lena et al, 2004; Tobler et al, 1997). The comparison between $\mathrm{H}$ and $\mathrm{NH}$ mice confirms and extends our previous data (El Yacoubi et al, 2003). Globally, $\mathrm{H}$ mice had fragmented sleep, with notably a shorter duration of SWS bouts and a greater number of wake episodes, higher amounts of $\mathrm{SWS}_{1}$ and REM sleep, and a shorter latency of this stage. These sleepwakefulness alterations in $\mathrm{H}$ mice are consistent with the data obtained in various depression models in the rat (Adrien et al, 1991; Dugovic et al, 2000; Nestler et al, 2002; Shiromani et al, 1988). Furthermore, they are reminiscent of sleep impairments observed in depressed patients, notably the sleep fragmentation, the shift towards lighter sleep stages, and the enhanced REM sleep pressure (Benca, 2000; Gillin et al, 1991).

With regard to the estrous cycle, in $\mathrm{NH}$ mice, no influence was observed on W or SWS, but REM sleep amounts were significantly decreased at the end of the dark period during the proestrous compared to the estrous phase. These data are in agreement with previous reports in rats, where low levels of REM sleep, but also of SWS, were found in the proestrous phase (Fang and Fishbein, 1996; Schwierin et al, 1998; Zhang et al, 1995). However, in contrast to rats (Schwierin et al, 1998), NH mice exhibited no variations in the EEG power spectra across the estrous cycle. The reduction of REM sleep during proestrous, when plasma levels of progesterone and estradiol are high (Schwierin et al, 1998), could be explained by the inhibitory influence of ovarian hormones on REM sleep (Fang and Fishbein, 1996; Schwierin et al, 1998). It has also been observed in women, who express reduced amounts of REM sleep in the luteal compared to the follicular phase (Baker et al, 2001), and only slight modifications of SWS all along the ovarian cycle (Driver et al, 1996).

In contrast to NH mice, no changes in W, SWS or REM sleep across the estrous cycle were observed in $\mathrm{H}$ mice. This might reflect a dysregulation of the hypothalamo-pituitarygonadal axis in these animals, as described in depressed women (Meller et al, 2001; Young et al, 2000). However, no problems in breeding have been observed in $\mathrm{H}$ mice (El Yacoubi et al, 2003).

\section{Muscarinic- and 5- $\mathrm{HT}_{1 \mathrm{~A}}$-Receptor-Mediated Regulations of REM Sleep}

Sleep patterns are under the regulatory influence of several neurotransmitter systems among which the cholinergic and serotoninergic ones are prominent, notably regarding REM sleep expression (Pace-Schott and Hobson, 2002; Shiromani et al, 1988). In particular, REM sleep is enhanced following treatments with cholinergic agonists in rats (Baghdoyan, 1997), mice (Coleman et al, 2004), and humans (Seifritz et al, 1998; Sitaram and Gillin, 1980). In contrast, REM sleep is inhibited by $5-\mathrm{HT}_{1 \mathrm{~A}}$ agonists (Boutrel et al, 1999; Driver et al, 1995; Tissier et al, 1993).

In the present work, we found that activation of muscarinic receptors by arecoline decreased REM sleep latency. Interestingly, this arecoline-induced facilitation of REM sleep was more marked in $\mathrm{H}$ than in $\mathrm{NH}$ mice, as observed in depressed patients compared with control subjects (Sitaram and Gillin, 1980). This enhanced facilitation could reflect a cholinergic hypersensitivity at the level of pontine REM sleep control system (Gillin et al, 1991; Seifritz et al, 1998). Along this line, the larger amounts of 
REM sleep in $\mathrm{H}$ mice under baseline conditions might be explained, at least in part, by a high muscarinic tone (Coleman et al, 2004), just as in the case of FSL (Flinders Sensitive Line) rats, another validated model of depression (Overstreet, 1993).

In contrast to muscarinic receptors, activation of $5-\mathrm{HT}_{1 \mathrm{~A}}$ receptors by $8-\mathrm{OH}-\mathrm{DPAT}$ induced a dose-dependent reduction of REM sleep amounts and an increase in REM sleep latency in both mouse lines, as observed in other mouse strains (Boutrel et al, 1999), in rats (Tissier et al, 1993), and also in humans (Driver et al, 1995). This effect is most probably accounted for by an agonist action of 8-OHDPAT at $5-\mathrm{HT}_{1 \mathrm{~A}}$ but not $5-\mathrm{HT}_{7}$ receptors (Wood et al, 2000). Indeed, selective blockade of $5-\mathrm{HT}_{1 \mathrm{~A}}$ receptors (by WAY 100,635) either enhanced REM sleep (Monaca et al, 2003), or completely suppressed the REM sleep inhibitory effect of 8-OH-DPAT in mice (Boutrel et al, 2002). In contrast, blockade of $5-\mathrm{HT}_{7}$ receptors has been found to reduce REM sleep (Thomas et al, 2003).

Interestingly, this REM sleep inhibitory response to 5$\mathrm{HT}_{1 \mathrm{~A}}$ receptor activation was similar in $\mathrm{H}$ and $\mathrm{NH}$ mice. This is in agreement with results obtained in depressed patients vs controls (Gillin et al, 1996; Seifritz et al, 1998), but it contrasts with the augmented hypothermia response to the same agonist found in $\mathrm{H}$ mice (El Yacoubi et al, 2003). This apparent discrepancy is due to the fact that the sleep response is mediated by post-synaptic $5-\mathrm{HT}_{1 \mathrm{~A}}$ receptors (Tissier et al, 1993), possibly at pontine level (Horner et al, 1997), whereas the hypothermic response is mediated by pre-synaptic (auto-) receptors (Goodwin et al, 1985). Indeed, the latter receptors are functionally hypersensitive in $\mathrm{H}$ mice (El Yacoubi et al, 2003), whereas the post-synaptic ones are unchanged, as observed under various experimental conditions (Fabre et al, 2000, Hensler, 2003).

In summary, the sleep/wakefulness alterations described in $\mathrm{H}$ mice mimic the alterations observed in depressed patients (Lustberg and Reynolds, 2000). As suggested for these patients, they could be accounted for by an imbalance between cholinergic and serotonergic tones. Such imbalance would be essentially due to an increase in cholinergic tone which would result notably in enhanced REM sleep (Gillin et al, 1991) and more frequent awakenings (Lustberg and Reynolds, 2000).

\section{Effect of Sleep Deprivation}

After $6 \mathrm{~h}$ of sleep deprivation, $\mathrm{NH}$ mice exhibited a significant increase in SWA during the first few hours of the recovery period, with no change in the total duration of SWS. These data confirm the results obtained in mice of other lines (Franken et al, 2001; Lena et al, 2004; Tobler et al, 1997), and are consistent with those in humans after one night of sleep deprivation (Borbely et al, 1981; Dijk and Beersma, 1989).

In contrast to $\mathrm{NH}$ mice, the $\mathrm{H}$ line exhibited no change in SWA, indicating an impairment of the homeostatic regulation of sleep in these mice, just like in depressed patients (Armitage et al, 2000; Borbely, 1987). Recombinant offsprings of $\mathrm{H}$ and $\mathrm{NH}$ mice might represent an interesting paradigm to investigate the genetic control of such a deficit in sleep homeostasis (Franken et al, 2001).

\section{Effect of Acute Stress}

A REM sleep rebound (50\% over baseline) was observed in $\mathrm{NH}$ mice from the 4th to the 9th $\mathrm{h}$ after the immobilization stress, as reported in mice of other lines (Boutrel et al, 2002; Lena et al, 2004) and in rats (Bouyer et al, 1998; Rampin et al, 1991). In contrast, $\mathrm{H}$ mice expressed no increase of REM sleep amounts after stress.

The impact of acute stress on sleep involves notably the HPA axis (Bouyer et al, 1998; Steiger, 2002). Indeed, we observed that $6 \mathrm{~h}$ after cessation of the immobilization stress, corticosterone levels had decreased to basal values in $\mathrm{NH}$ mice, but were still elevated in $\mathrm{H}$ mice, thereby preventing the occurrence of the REM sleep rebound (Boutrel et al, 2002). Interestingly, the return of corticosterone to baseline level is under cholinergic control in the hippocampus (Han et al, 2002). Thus, a functional deficit of hippocampal muscarinic receptors in $\mathrm{H}$ mice could be responsible, at least in part, for the delay in corticosterone decline after stress, and in turn for the absence of REM sleep rebound. Finally, like in other models of depression (Ladd et al, 2004; Prathiba et al, 1998) and in depressed patients (Arborelius et al, 1999), dysregulation of HPA axis is observed in $\mathrm{H}$ mice (El Yacoubi et al, 2003), an impairment which would alter their stress-induced adaptive response of REM sleep.

\section{Physiopathological Implications}

In terms of the relation between sleep disorders and depression, the present model can lead to various comments and questions. Firstly, like most models, it does not entirely mimic the very complex pattern of sleep impairments associated with depression. In particular, one would expect to observe in a depression model some manifestations of insomnia, and notably an increase in wakefulness (Lustberg and Reynolds, 2000). This was not the case for $\mathrm{H}$ mice that exhibited decreased wakefulness. In the same manner, we found no abnormality of delta power during deep SWS in $\mathrm{H}$ mice, whereas this is a constant feature of depression, especially in women (Armitage et al, 2000). However, depressed patients suffer also decreased sleep continuity, difficulties falling asleep and maintaining sleep, and early morning awakenings. Globally, the present model mimics these characteristics, illustrated by sleep fragmentation and the frequent awakenings. In addition, deficits in locomotor activity, REM sleep alterations, and sleep homeostasis deficiency also evoke the impairments found in depressed patients (Armitage et al, 2000; Lustberg and Reynolds, 2000).

Along this line, one can ask whether sleep impairments in $\mathrm{H}$ mice represent trait- or state-dependent characteristics. In depressed patients, sleep disorders may persist in a milder form during periods of remission, suggesting they may be a trait marker of depression (Lustberg and Reynolds, 2000). In the same manner, the sleep impairments observed in $\mathrm{H}$ mice might be trait-related. As in patients, sleep disorders, and notably decreased REM sleep latency, should aggravate under conditions of a 'depressive episode' (Lustberg and Reynolds, 2000). Analysis of sleep patterns in $\mathrm{H} v s \mathrm{NH}$ mice after chronic stress should allow to clarify this point. 
In summary, $\mathrm{H}$ mice exhibit sleep alterations that include fragmented sleep, lighter SWS, increased REM sleep pressure, and lack of influence of the ovarian cycle on sleep. Moreover, their response to behavioural and pharmacological challenges indicates changes in the muscarinic component of the REM sleep regulatory mechanisms, and deficits in adaptive responses to sleep deprivation and acute stress. Since these alterations evoke those found in depressed patients, this model might be of particular interest for investigating mechanisms and molecular targets for alleviating depression-related sleep disorders.

\section{ACKNOWLEDGEMENTS}

This research was supported by Institut National de la Santé et de la Recherche Médicale, Centre National de la Recherche Scientifique, Université Pierre et Marie Curie and European Community (Program 'Newmood'-Contract nb LSHM-CT-2003-503474, FWP6). During performance of this study, DP was supported by a grant from La Fondation pour la Recherche Médicale (FRM) and MEY by grants from Société Française de Recherche sur le Sommeil and Sanofi-Aventis France.

\section{REFERENCES}

Adrien J (2002). Neurobiological bases for the relation between sleep and depression. Sleep Med Rev 6: 341-351.

Adrien J, Dugovic C, Martin P (1991). Sleep-wakefulness patterns in the helpless rat. Physiol Behav 49: 257-262.

Arborelius L, Owens MJ, Plotsky PM, Nemeroff CB (1999). The role of corticotropin-releasing factor in depression and anxiety disorders. J Endocrinol 160: 1-12.

Armitage R, Hoffmann R, Trivedi M, Rush AJ (2000). Slow-wave activity in NREM sleep: sex and age effects in depressed outpatients and healthy controls. Psychiatry Res 95: 201-213.

Avery DH, Shah SH, Eder DN, Wildschiodtz G (1999). Nocturnal sweating and temperature in depression. Acta Psychiatr Scand 100: 295-301.

Baghdoyan HA (1997). Location and quantification of muscarinic receptor subtypes in rat pons: implications for REM sleep generation. Am J Physiol 273: R896-R904.

Baker FC, Waner JI, Vieira EF, Taylor SR, Driver HS, Mitchell D (2001). Sleep and $24 \mathrm{~h}$ body temperatures: a comparison in young men, naturally cycling women and women taking hormonal contraceptives. J Physiol 530: 565-574.

Barden N, Reul JM, Holsboer F (1995). Do antidepressants stabilize mood through actions on the hypothalamic-pituitary-adrenocortical system? Trends Neurosci 18: 6-11.

Benca R (2000). Mood disorders. In: Kryger M, Roth T, Dement W (eds). Principles and Practice of Sleep Medecine. Saunders: Philadelphia. pp 1140-1158.

Borbely AA (1987). The S-deficiency hypothesis of depression and the two-process model of sleep regulation. Pharmacopsychiatry 20: 23-29.

Borbely AA, Baumann F, Brandeis D, Strauch I, Lehmann D (1981). Sleep deprivation: effect on sleep stages and EEG power density in man. Electroencephalogr Clin Neurophysiol 51: 483-495.

Boutrel B, Franc B, Hen R, Hamon M, Adrien J (1999). Key role of 5 -HT1B receptors in the regulation of paradoxical sleep as evidenced in 5-HT1B knock-out mice. J Neurosci 19: 3204-3212.

Boutrel B, Monaca C, Hen R, Hamon M, Adrien J (2002). Involvement of 5-HT1A receptors in homeostatic and stressinduced adaptive regulations of paradoxical sleep: studies in 5-HT1A knock-out mice. J Neurosci 22: 4686-4692.
Bouyer JJ, Vallee M, Deminiere JM, Le Moal M, Mayo W (1998). Reaction of sleep-wakefulness cycle to stress is related to differences in hypothalamo-pituitary-adrenal axis reactivity in rat. Brain Res 804: 114-124.

Bunney WE, Bunney BG (2000). Molecular clock genes in man and lower animals: possible implications for circadian abnormalities in depression. Neuropsychopharmacology 22: 335-345.

Coleman CG, Lydic R, Baghdoyan HA (2004). M2 muscarinic receptors in pontine reticular formation of $\mathrm{C} 57 \mathrm{BL} / 6 \mathrm{~J}$ mouse contribute to rapid eye movement sleep generation. Neuroscience 126: 821-830.

Dijk DJ, Beersma DG (1989). Effects of SWS deprivation on subsequent EEG power density and spontaneous sleep duration. Electroencephalogr Clin Neurophysiol 72: 312-320.

Driver HS, Dijk DJ, Werth E, Biedermann K, Borbely AA (1996). Sleep and the sleep electroencephalogram across the menstrual cycle in young healthy women. J Clin Endocrinol Metab 81: 728-735.

Driver HS, Flanigan MJ, Bentley AJ, Luus HG, Shapiro CM, Mitchell D (1995). The influence of ipsapirone, a 5-HT1A agonist, on sleep patterns of healthy subjects. Psychopharmaco$\log y$ (Berlin) 117: 186-192.

Dugovic C, Solberg LC, Redei E, Van Reeth O, Turek FW (2000). Sleep in the Wistar-Kyoto rat, a putative genetic animal model for depression. Neuroreport 11: 627-631.

El Yacoubi M, Bouali S, Popa D, Naudon L, Leroux-Nicollet I, Hamon $M$ et al (2003). Behavioral, neurochemical, and electrophysiological characterization of a genetic mouse model of depression. Proc Natl Acad Sci USA 100: 6227-6232.

Fabre V, Beaufour C, Evrard A, Rioux A, Hanoun N, Lesch KP et al (2000). Altered expression and functions of serotonin 5-HT1A and 5-HT1B receptors in knock-out mice lacking the 5-HT transporter. Eur J Neurosci 12: 2299-2310.

Fang J, Fishbein W (1996). Sex differences in paradoxical sleep: influences of estrus cycle and ovariectomy. Brain Res 734: 275-285.

Franken P, Chollet D, Tafti M (2001). The homeostatic regulation of sleep need is under genetic control. J Neurosci 21: 2610-2621.

Franken P, Malafosse A, Tafti M (1998). Genetic variation in EEG activity during sleep in inbred mice. Am J Physiol 275: R1127R1137.

Gillin JC, Sohn JW, Stahl SM, Lardon M, Kelsoe J, Rapaport M et al (1996). Ipsapirone, a 5-HT1A agonist, suppresses REM sleep equally in unmedicated depressed patients and normal controls. Neuropsychopharmacology 15: 109-115.

Gillin JC, Sutton L, Ruiz C, Kelsoe J, Dupont RM, Darko D et al (1991). The cholinergic rapid eye movement induction test with arecoline in depression. Arch Gen Psychiatry 48: 264-270.

Goodwin GM, De Souza RJ, Green AR (1985). The pharmacology of the hypothermic response in mice to 8-hydroxy-2-(din-propylamino)tetralin (8-OH-DPAT). A model of presynaptic 5-HT1 function. Neuropharmacology 24: 1187-1194.

Grino M, Guillaume V, Castanas E, Boudouresque F, Conte-Devolx B, Oliver C (1987). Effect of passive immunization against corticotropin-releasing factor (CRF) on the postadrenalectomy changes of CRF binding sites in the rat anterior pituitary gland. Neuroendocrinology 45: 492-497.

Han JS, Bizon JL, Chun HJ, Maus CE, Gallagher M (2002). Decreased glucocorticoid receptor mRNA and dysfunction of HPA axis in rats after removal of the cholinergic innervation to hippocampus. Eur J Neurosci 16: 1399-1404.

Hasler G, Drevets WC, Manji HK, Charney DS (2004). Discovering endophenotypes for major depression. Neuropsychopharmacology 29: 1765-1781.

Hensler JG (2003). Regulation of 5-HT1A receptor function in brain following agonist or antidepressant administration. Life Sci 72: $1665-1682$. 
Horner RL, Sanford LD, Annis D, Pack AI, Morrison AR (1997). Serotonin at the laterodorsal tegmental nucleus suppresses rapid-eye-movement sleep in freely behaving rats. J Neurosci 17: 7541-7552.

Kapitany T, Schindl M, Schindler SD, Hesselmann B, Fureder T, Barnas C et al (1999). The citalopram challenge test in patients with major depression and in healthy controls. Psychiatry Res 88: 75-88.

Ladd CO, Huot RL, Thrivikraman KV, Nemeroff CB, Plotsky PM (2004). Long-term adaptations in glucocorticoid receptor and mineralocorticoid receptor mRNA and negative feedback on the hypothalamo-pituitary-adrenal axis following neonatal maternal separation. Biol Psychiatry 55: 367-375.

Lena C, Popa D, Grailhe R, Escourrou P, Changeux JP, Adrien J (2004). Beta2-containing nicotinic receptors contribute to the organization of sleep and regulate putative micro-arousals in mice. J Neurosci 24: 5711-5718.

Lustberg L, Reynolds CF (2000). Depression and insomnia: questions of cause and effect. Sleep Med Rev 4: 253-262.

Meller WH, Grambsch PL, Bingham C, Tagatz GE (2001). Hypothalamic pituitary gonadal axis dysregulation in depressed women. Psychoneuroendocrinology 26: 253-259.

Monaca C, Boutrel B, Hen R, Hamon M, Adrien J (2003). 5-HT 1A/ $1 \mathrm{~B}$ receptor-mediated effects of the selective serotonin reuptake inhibitor, citalopram, on sleep: studies in 5-HT 1A and 5-HT 1B knockout mice. Neuropsychopharmacology 28: 850-856.

Neckelmann D, Ursin R (1993). Sleep stages and EEG power spectrum in relation to acoustical stimulus arousal threshold in the rat. Sleep 16: 467-477.

Nestler EJ, Gould E, Manji H, Buncan M, Duman RS, Greshenfeld HK et al (2002). Preclinical models: status of basic research in depression. Biol Psychiatry 52: 503-528.

Overstreet DH (1993). The Flinders sensitive line rats: a genetic animal model of depression. Neurosci Biobehav Rev 17: 51-68.

Pace-Schott EF, Hobson JA (2002). The neurobiology of sleep: genetics, cellular physiology and subcortical networks. Nat Rev Neurosci 3: 591-605.

Prathiba J, Kumar KB, Karanth KS (1998). Hyperactivity of hypothalamic pituitary axis in neonatal clomipramine model of depression. J Neural Transm 105: 1335-1339.

Rampin C, Cespuglio R, Chastrette N, Jouvet M (1991). Immobilisation stress induces a paradoxical sleep rebound in rat. Neurosci Lett 126: 113-118.

Schwierin B, Borbely AA, Tobler I (1998). Sleep homeostasis in the female rat during the estrous cycle. Brain Res 811: 96-104.
Seifritz E, Gillin JC, Rapaport MH, Kelsoe JR, Bhatti T, Stahl SM (1998). Sleep electroencephalographic response to muscarinic and serotonin1A receptor probes in patients with major depression and in normal controls. Biol Psychiatry 44: 21-33.

Shiromani PJ, Overstreet D, Levy D, Goodrich CA, Campbell SS, Gillin JC (1988). Increased REM sleep in rats selectively bred for cholinergic hyperactivity. Neuropsychopharmacology 1: 127-133.

Sitaram N, Gillin JC (1980). Development and use of pharmacological probes of the CNS in man: evidence of cholinergic abnormality in primary affective illness. Biol Psychiatry 15: 925-955.

Solberg LC, Olson SL, Turek FW, Redei E (2001). Altered hormone levels and circadian rhythm of activity in the WKY rat, a putative animal model of depression. Am J Physiol Regul Integr Comp Physiol 281: R786-R794.

Souetre E, Salvati E, Belugou JL, Pringuey D, Candito M, Krebs B et al (1989). Circadian rhythms in depression and recovery: evidence for blunted amplitude as the main chronobiological abnormality. Psychiatry Res 28: 263-278.

Steiger A (2002). Sleep and the hypothalamo-pituitary-adrenocortical system. Sleep Med Rev 6: 125-138.

Thomas DR, Melotto S, Massagrande M, Gribble AD, Jeffrey P, Stevens AJ et al (2003). SB-656104-A, a novel selective 5-HT7 receptor antagonist, modulates REM sleep in rats. $\mathrm{Br} J$ Pharmacol 139: 705-714.

Tissier MH, Lainey E, Fattaccini CM, Hamon M, Adrien J (1993). Effects of ipsapirone, a 5-HT1A agonist, on sleep/wakefulness cycles: probable post-synaptic action. J Sleep Res 2: 103-109.

Tobler I, Borbely AA (1990). The effect of 3-h and 6-h sleep deprivation on sleep and EEG spectra of the rat. Behav Brain Res 36: 73-78.

Tobler I, Deboer T, Fischer M (1997). Sleep and sleep regulation in normal and prion protein-deficient mice. J Neurosci 17: $1869-1879$.

Willner P (1990). Animal models of depression: an overview. Pharmacol Ther 45: 425-455.

Wood M, Chaubey M, Atkinson P, Thomas DR (2000). Antagonist activity of meta-chlorophenylpiperazine and partial agonist activity of 8-OH-DPAT at the 5-HT(7) receptor. Eur J Pharmacol 396: 1-8.

Young EA, Midgley AR, Carlson NE, Brown MB (2000). Alteration in the hypothalamic-pituitary-ovarian axis in depressed women. Arch Gen Psychiatry 57: 1157-1162.

Zhang SQ, Kimura M, Inoue S (1995). Sleep patterns in cyclic and pseudopregnant rats. Neurosci Lett 193: 125-128. 